\title{
THE EFFECT OF FISHERMEN EMPOWERMENT TOWARDS THEIR WORKING ABILITY IN EAST LOMBOK
}

\author{
Sulkiah*, Setiawina N. Djinar, Budhi Made Kembar Sri, Yasa I G. W. Murjana \\ Economics and Business Faculty, University of Udayana, Bali, Indonesia \\ *E-mail: chunk6@yahoo.com
}

\begin{abstract}
This research is motivated by the phenomenon of empowerment that does not show results in an effort to increase the working ability of fishermen. Various trainings have been carried out to improve working ability, including assistance from the government and the private sector, but still have not shown an increase in the empowerment of East Lombok fishermen. Therefore, the empowerment of East Lombok fishermen was examined in this study. This study aims to determine the effect of fishermen empowerment towards their working ability in east Lombok. Data was obtained through questionnaires to 171 fishermen respondents in East Lombok, interviews with community leaders related institutions, and field observations. The analysis was carried out descriptively and quantitatively. Descriptive analysis explains the indicators that have a score above and below the average total score for each variable. Quantitative analysis uses SEM with PLS applications to determine the level of significance between variables as mentioned in the research objectives. The results showed that empowerment had a positive and significant effect on fishermen working ability. This means that the empowerment of the East Lombok fishing community must continue to be improved to improve the empowerment of fishermen. Variables that have a significant effect must be increased to improve the welfare of fishermen in East Lombok.
\end{abstract}

\section{KEY WORDS}

Empowerment, working ability, fishing, East Lombok, community.

The issue of poverty is a major topic in the lives of fishermen. Increasing the empowerment of fishermen is needed to be able to get out of the present situation. Various empowerment programs have been carried out to increase the empowerment of fishermen, but still not able to remove fishermen from the deterioration experienced today. Poverty causes the powerlessness of fishermen to access resources. In an effort to improve the welfare of the community in coastal areas empowerment is needed to increase the working ability of fishermen. Community empowerment is a concept that arises because of the assumptions about failure of development which tend to be centralized. The aim of community empowerment is to enable and empower the community, especially from poverty and underdevelopment / disparity / powerlessness.

Therefore the purpose of this study is to analyze the effect of empowerment on working ability.

\section{LITERATURE REVIEW}

Working ability is a condition or outcome of a process or activity of empowerment. Power is a basic word of empowerment which means strength that comes from within, but can also be strengthened through elements from outside (Theresia et al., 2014). Empowerment is a condition where individuals have the power or ability (power / power) to maximize their potential to achieve prosperity. According to Kartasasmita (1996), empowerment is an element that enables individuals, organizations or communities to survive and be dynamic, and can develop themselves to achieve their goals or welfare.

Empowerment is a series of activities to strengthen the strength or empowerment of vulnerable and weak groups in society, including individuals who experience poverty problems, so that they have empowerment in fulfilling their life needs both physically, 
economically, and socially such as: self-confidence, and expressing aspirations, have livelihood, participate in social activities and establish in carrying out their life tasks (Suharto, 2005). The way in which is carried out in the process of empowerment is by providing motivation or support in the form of resources, opportunities, knowledge, and skills for the community to increase their capacity, increase awareness about the potential they have, then try to develop the potential they have.

\section{METHODS OF RESEARCH}

This study seeks to find relationships between variables so that it is a relational study. This study seeks to find a relationship between empowerment variables and the working ability variables of fishermen. The analysis unit is located in the unit of the fishermen's head of family. This research was conducted in East Lombok. The object of research is sustainability in research with empowerment. Therefore, the subjects of the study were the heads of households selected as samples in East Lombok.

The population in this study was fisherman households in East Lombok with a total of 4571. Samples were taken purposively which were fisherman households in the target area of the study. Of the population of 4,571 sample households tolerated by 10 percent.

$$
n=\frac{4571}{1+4571(0,075)^{2}}=171
$$

So the number of samples taken was 171 fishermen.

In this study, structural equation analysis (SEM) was used by alternative Partial Square Least PLS (component based SEM). Testing the hypothesis of direct influence using the bootstrap resampling method using statistical tests $t$. If the $t$-statistic value (t count) $>t$-table then the hypothesis is accepted, and vice versa. In addition, a comparison between the $p$ value and alpha $(\alpha)$ can be made. If $p$-value $\leq 0.05$ (alpha 5 percent) is obtained, it is concluded that it is significant, and vice versa.

\section{RESULTS OF STUDY}

The questionnaire distributed to respondents was 171 copies. The collected data includes the identity of the respondent, household characteristics, business characteristics and ordinal data information that extracts information from fishermen using a Likert scale. In addition, the opinions of fishermen on the existence of the government are also explored: do fishermen feel helped or not by the fishermen's empowerment program and what the reasons are. From the questionnaires distributed and filled in completely by the respondents, there are several things that are of concern, especially the empowerment process which has not been able to increase the empowerment of fishermen.

Based on the results of data analysis, all constructs are positively and significantly related to each other with the probability of acceptance of the hypothetical zero less than 1 percent as shown in Table 1.

Table 1 - Empowerment, Empowerment of East Lombok fishermen, 2018

\begin{tabular}{llllll}
\hline Relationship between Variables & Loading & Std. Error & $\mathrm{t}$-statistic & $\mathrm{p}$ value & Information \\
\hline Empowerment $\rightarrow$ Working ability $(\mathrm{Y} 1)$ & 0.226 & 0.086 & 2.267 & 0.009 & Significant \\
\hline
\end{tabular}

Based on Table 1 above, it can be concluded that empowerment has a positive effect on fishermen working ability. The effect of empowerment on fishermen working ability shows a value of 0.226 (positive) with a t-statistic value of 2.267. These two figures indicate that the empowerment variable influences the working ability of fishermen. This is in accordance with the research from Sumodiningrat (1998) which states that the empowerment of the poor needs to be directed at changing the coping strategies of the poor to be better based on the needs and expectations of the poor. at the local level. Planning and implementation of 
empowerment should contain efforts to strengthen their productive economic efforts based on their "views and needs", so that the poor have access to independent socio-economic and political resources. To improve the ability of the poor, at least there must be improved socioeconomic and cultural accessibility of four things, namely: (1) access to natural resources, (2) more efficient access to technology, (3) access to markets and (4) access to financing sources.

Furthermore Wahyono, al. (2001), states that empowerment of poor coastal communities in Pantai village is a series of efforts with a range of activities that touch the fulfillment of various kinds of access and basic needs for food, education, housing and health, including meeting the need to participate in poverty reduction them, so that all members of the poor in coastal villages can be independent, confident, not dependent and able to be free from the shackles of socio-cultural and economic structures that make them poor.

\section{CONCLUSION}

Based on the results of data analysis it can be concluded, Empowerment has a positive and significant effect on empowerment. The better the empowerment efforts aimed at households, the more empowerment and improvement in quality of life will become stronger.

The contribution in this study is:

To improve fishermen's working ability, they are focused on external empowerment. Internal factors will be able to support external factors as a government effort in alleviating poverty. Lack of working capital inhibits empowerment and well-being, this has consequences for all parties to eliminate negative culture, by socializing that consumptive expenditures such as expenses for kinship ceremonies, should be adjusted to capacity so that income can be used for productive matters.

The findings of this study can be used as a reference or reference by the government, especially the East Lombok Regency government in overcoming the problems of fishermen's working ability faced by their communities. The increase in community empowerment that has been carried out by the government is more of a routine program without touching on the substantial problems faced by fishermen families, resulting in the view that the government behaves as benefactors which results in fishermen always waiting for government obligations to help with their living needs. This situation creates a culture of sustainable poverty without regard to its empowerment.

\section{REFERENCES}

1. Aprillia, Theresia. Dkk. 2014. Pembangunan Berbasis Masyarakat. Bandung, Alfabeta.

2. Ary Wahyono, dkk (ed.). 2001. "Kata Pengantar" dalam Pemberdayaan Masyarakat Nelayan, Yogyakarta: Media Pressindo.

3. Kartasasmita, Ginandjar. 1996. Pembangunan Untuk Rakyat. Memadukan Pertumbuhan and Pemerataan, Penerbit PT. pustaka CIDESINDO, Jakarta.

4. Suharto, Edi. 2005. Membangun Masyarakat Memberdayakan Rakyat Kajian Strategis Pembangunan Kesejahteraan Sosial and Pekerjaan Sosial. Cetakan kedua. Bandung: Aditama.

5. Sumodiningrat, Gunawan. 1998. Membangun Perekonomian Rakyat, Yogyakarta: Pustaka Pelajar. 